\title{
Application of Sub-bituminous Coal Activated with Urea to Improve Chemical Properties of Ultisols and Palm Oil's Growth (Elaeis Guineensis Jacq.) In Pulau Punjung, Dharmasraya
}

\author{
Herviyanti ${ }^{\mathrm{a},}$, Amsar Maulana ${ }^{\mathrm{a}}$, Teguh B. Pasetyo ${ }^{\mathrm{a}}$, Trisa Omily ${ }^{\mathrm{a}}$, Ridho Ryswaldi ${ }^{\mathrm{b}}$ \\ ${ }^{a}$ Department of Soil Science, Faculty of Agriculture, Universitas Andalas, Limau Manis, Padang, West Sumatra 25163 Indonesia \\ ${ }^{b}$ Department of Management, Faculty of Economic, Universitas Andalas, Padang, West Sumatra 25163, Indonesia \\ Corresponding author: "herviyanti@agr.unand.ac.id
}

\begin{abstract}
Ultisols are a type of suboptimal land with low fertility, so it is necessary to add ameliorants such as Sub-bituminous (unproductive young coal as an energy source) to increase soil fertility. This study aimed to examine the effect of Sub-bituminous coal activated by Urea in improving the chemical properties of Ultisols and the growth of oil palm. The study was conducted in Nagari Sungai Dareh, Pulau Punjung, Dharmasraya West Sumatra using a Randomized Block Design with 6 treatments and 3 groups. The treatments are the dose of Sub-bituminous coal (g (planting hole) ${ }^{-1}$ ) and Urea fertilizer, which is $A=150 ; B=300 ; C=450 ; D=150+$ $10 \%$ Urea; $E=300+10 \%$ Urea; and $F=450+10 \%$ Urea. The results showed that the administration of Sub-bituminous coal at a dose of $450 \mathrm{~g}$ (planting hole) ${ }^{-1}$ activated by $10 \%$ Urea was able to improve the chemical properties of Ultisols such as increasing the soil pH by 0.57 units; total-N by $0.13 \%$; organic-C by $0.69 \%$; available $P$ by 3.25 ppm; CEC by $16,14 \mathrm{cmol}_{\mathrm{c}} \mathrm{kg}^{-1}$ and can reduce of Alexch to immeasurable compared to $150 \mathrm{~g}$ (planting hole) ${ }^{-1}$. Sub-bituminous coal activated by $10 \%$ Urea increases oil palm growth (Elaeis guineensis Jacq.). Increasing plant growth was found in $450 \mathrm{~g}$ (planting hole) ${ }^{-1}+10 \%$ Urea with an increase in plant height by $48.34 \mathrm{~cm}$, the number of midribs of 4 strands, stem diameter by $1.71 \mathrm{~cm}$, and nutrient plant of $N, P$ and $K$ by $0.014 ; 0.005 ;$ and $0.003 \%$.
\end{abstract}

Keywords—Palm oil; sub-bituminous coal; ultisols; Urea.

Manuscript received 28 Nov. 2020; revised 11 Jan. 2021; accepted 1 Feb. 2021. Date of publication 30 Apr. 2021. IJASEIT is licensed under a Creative Commons Attribution-Share Alike 4.0 International License.

\section{INTRODUCTION}

Sub-optimal dry land is in acid mineral soils dominated by Ultisols, which is \pm 45.79 million ha $(24.3 \%)$ of Indonesian land spread across Sumatra, Kalimantan, and Irian [1]. This acid mineral soil is less productive for plants, both food crops, and plantations, because of low land productivity, acid soil reaction, and can absorb large amounts of P. Ultisols is a soil order formed in wet tropical regions that have undergone weathering and a very advanced process of climate destruction that causes leaching of soil nutrients and bases to the lower layers [2]. As a result, the surface of the soil that experiences leaching reacts sourly to very sour. In comparison, $\mathrm{Al}$ and Fe oxides and some metal oxides that are resistant to weathering are left behind.

Efforts to overcome the problem of the poisoning of heavy metals ( $\mathrm{Al}$ and $\mathrm{Fe}$ ) and nutrient deficiencies can be made by adding organic matter to the soil. However, organic materials that are often used, such as manure, green manure, and compost, require weathering processes that are long enough to react in the soil. Through this research, organic components that respond quickly, the most active in the soil with an electric charge and cation exchange capacity (CEC) larger than clay minerals, are the dominant humic substance found in unproductive coal (Sub-bituminous).] Humic substance (HS) that was able to be extracted from Subbituminous reached $31.5 \%$ [3], [4].

HS from Sub-bituminous coal originating from Bonjol, Pasaman could increase $\mathrm{P}$ fertilization efficiency and the productivity of marginal soils planted with corn and rice. After comparing it with compost, it turns out to have the same ability, while the number of Sub-bituminous needed is only one-third of the compost amount because the humic substance of Sub-bituminous is higher than compost $(31.5 \%$ compared to $11.0 \%$ ) [5]. Thus low-rank coal, which is not productive as an energy source, can be processed as an 
alternative source of organic material to increase the productivity of Ultisols.

HS can be obtained using an alkaline solvent at a concentration of 0.1 to $0.5 \mathrm{~N}$, such as $\mathrm{NaOH}$. Other solvents that are also alkaline and at the same time are macro and lime fertilizers commonly used by farmers, such as Urea and dolomite. Using Urea and dolomite fertilizer, humic substances containing fertilizers and lime will be obtained so that it is more efficient in applying organic materials and inorganic fertilizers, and lime on acid mineral soils. HS from young coal (Lignite and Sub-bituminous coal) has nondegradable properties (meaning resistant/resistant properties) to biological and chemical destruction for up to 10-50 years [6]. Because of the nature of the resistance of the HS, the application of artificial fertilizers can be gradually reduced, and agricultural, and plantation businesses become more economical. The problem of providing fertilizer that is often scarce can also be overcome by increasing its use by mixing with Sub-bituminous coal.

Urea, $\mathrm{KCl}$, and $\mathrm{NaCl}$ were able to dissolve Subbituminous coal and produce humic substances, although Urea had a higher ability than $\mathrm{KCl}$ and $\mathrm{NaCl}$ [7]. The solubility of coal with Urea solvent can match $\mathrm{NaOH}$ solvents' results, which are commonly used to dissolve HS from coal. Sub-bituminous coal of $0.25 \%$ and $0.50 \%$ with Urea and $\mathrm{KCl}$ measuring $125 \%$ recommendations and $\mathrm{NaCl}$ and $\mathrm{NaOH} 0.25 \mathrm{~N}$ reported that the growth of corn plants for treatment with Sub-bituminous coal was almost as good as the humic extracted [8]. Sub-bituminous coal provision with some activators can increase corn crop yield by $66.55 \%$ and $62.28 \%$ compared to controls and $54.19 \%$ and $50.23 \%$ compared without activators. This shows that the application of Sub-bituminous coal as an energy source can also be used as an active ameliorant in the soil. How the activity and ability of this coal powder when activated by Urea, dolomite and $\mathrm{NaOH}$ fertilizers in improving the chemical and physical properties of Ultisols soil, increasing the efficiency of artificial fertilizers for the growth of oil palm plants in Dharmasraya Regency, West Sumatra Province, is not yet known so this research was conducted. Mixing Subbituminous coal with the activating agent is expected to be able to activate the HS without the need to extract it first.

In this research, oil palm plantations (Elaeis guineensis Jacq.) are used as indicators because they have good prospects for development on marginal soils in Indonesia. Marginal land in Indonesia is around 39.4 million hectares spread across Sumatra, Kalimantan, and Papua. The prospect of this marginal land is big enough for oil palm development in Indonesia. This study was the ability of activated Subbituminous coal in improving the chemical properties of Ultisols in Dharmasraya, West Sumatra to support the growth of oil palm plants.

\section{MATERIAL AND METHOD}

This research was conducted in Filed Nagari Sungai Dareh, Pulau Punjung, Dharmasraya West Sumatra, and the Laboratory of Soil Chemistry and Fertility of the Soil Department and Experimental Garden of the Agricultural Faculty, Andalas University, Padang from December 2018 to December 2019.

\section{A. Sub-bituminous Coal, Urea and Soil Sampling}

Sub-bituminous coal was collected at 1-2 m depth below the soil surface in Ganggo Mudiak Nagari, Pasaman of West Sumatera. Sub-bituminous coal was cleaned, mashed, and sieved using $125 \mu \mathrm{m}$ sieve. Urea is one type of inorganic fertilizer that is sold in the market. The Urea $\left[\left(\mathrm{NH}_{2}\right)_{2} \mathrm{CO}\right]$ fertilizer is chemical fertilizer containing a high level of Nitrogen $(\mathrm{N})$. The nitrogen element is a much-needed plant nutrient shaped like white crystal and a water-soluble thistle, and extremely water-absorbing (hygroscopic). The Urea fertilizer contains $46 \% \mathrm{~N}$ with the mean of $100 \mathrm{~kg}$ containing $46 \mathrm{~kg}$ of $\mathrm{N}$, Moisture $0.5 \%$, Biuret rate of $1 \%$, size $-3.3 \mathrm{MM}$ 90\% Min and Prill form, and SNI Standart 2801:2010 (PT. Pupuk Sriwijaya Palembang). Ultisols were taken from Nagari Sungai Dareh, Pulau Punjung, Dharmasraya West Sumatra.

\section{B. Experimental Design}

The experimental design was in Randomized Complete Block Design with three replications consisting of 7 treatments: $\mathrm{K}=$ Control; $\mathrm{A}=150 \mathrm{~g} ; \mathrm{B}=300 \mathrm{~g} ; \mathrm{C}=450 \mathrm{~g}$ (planting hole) $^{-1} ; \mathrm{D}=150 \mathrm{~g} ; \mathrm{E}=300 \mathrm{~g}$ and $\mathrm{F}=450 \mathrm{~g}$ (planting hole $)^{-1}+10 \%$ of Urea.

\section{Land Preparation, Activation Process and Incubation Sub-bituminous Coal on Soil}

The land is cleared of weeds, and initial soil sampling is carried out. The planting hole is prepared with size $(50 \mathrm{~cm} \mathrm{x}$ $30 \mathrm{~cm} \times 60 \mathrm{~cm}$ ) with a spacing of $9 \mathrm{~m}$. The hole is left open for 2 weeks. After that, the young coal powder, which Urea has activated according to the treatment, is stirred with the excavated soil and added water until it is moist, then put into the planting hole and incubated for 2 more weeks by closing the hole using black plastic. After that, the soil is taken for analysis of changes in soil chemical properties of Ultisols after treatment.

Sub-bituminous coal was activated with Urea at each dose of treatment, added water until field capacity, evenly mixed, and incubated 10 days. The palm oil seedlings used are 9month-old seeds. Seedlings are planted when the incubation period is complete, and subsequent growth of palm oil seedlings is observed in the field. The support plant growth, Urea, $\mathrm{KCl}$, and SP-36 fertilizers are given according to recommendations. Fertilization is done on the circumference of a tree or tree disc. When applying fertilizer is also based on the age of the plant. Plant maintenance includes pest and disease control and watering if it does not rain for 3 days in a row.

\section{Analysis of Soil and Plant}

The chemical properties of Ultisols analyzed included: the soil $\mathrm{pH} \mathrm{H}_{2} \mathrm{O}$ (1:1) using the electrometric method, CEC with leaching method, organic $\mathrm{C}$ with Walkley and Black method, $\mathrm{N}$ total with Kjehdhal method, available $\mathrm{P}$ with Bray method, and Al-exch (exchangeable) with the volumetric method. Later, four-month-old palm oil pre-nursery seedlings were planted, maintained, and observed for their growth for four months (main-nursery). The plant's vegetative stage was harvested for the analysis of the nutrient level of $\mathrm{N}, \mathrm{P}$, and $\mathrm{K}$ [9]. Observation of plants includes plant height measured when plant age 2-months after planting, stem diameter, and 
the number of midribs measured 1-month after planting and so on until the sixth month.

\section{E. Statistical Analysis}

The statistical analysis has carried the software Statistix 8 and Excel 2016 to analyze sub-bituminous coal activation. It submitted to an analysis of variance, and when significant $(F$ test $\mathrm{p}<0.05$ ), the mean was compared using Duncan's new multiple range tests $\left\{\mathrm{p}<0.05\right.$ or $\mathrm{F}$ test $>\mathrm{F}$ table $5 \%\left(^{*}\right)$ and $1 \%(* *)\}$

\section{RESULTS AND DISCUSSION}

The chemical characteristics of Ultisols Nagari Dareh, Sungai Punjung, Dharmasraya were assessed based on the criteria table presented in Table 1 , that the soil $\mathrm{pH}$ included acidity, CEC, Organic C, total-N, available of $\mathrm{P}$ and cation base were classified as low. In contrast, Al saturation was classified as high. This condition shows that the soil used has a low fertility rate, and if it is not repaired, it will be a cause of stunted plant growth.

TABLE I

CHARACTERISTICS CHEMICAL PROPERTIES OF ULTISOL IN PULAU PUNJUNG, DHARMASRAYA WEST SUMATRA

\begin{tabular}{|c|c|c|c|}
\hline Parameters & Unit & Value & Criteria [9] \\
\hline $\mathrm{pH} \mathrm{H}_{2} \mathrm{O}(1: 1)$ & unit & 4.54 & Acid \\
\hline Al-exch & $\mathrm{cmol}_{\mathrm{c}} \mathrm{kg}^{-1}$ & 3.64 & - \\
\hline K-exch & $\mathrm{cmol}_{\mathrm{c} \mathrm{kg}} \mathrm{kg}^{-1}$ & 0.34 & Low \\
\hline Ca-exch & $\mathrm{cmol}_{\mathrm{c}} \mathrm{kg}^{-1}$ & 2.38 & Low \\
\hline Mg-exch & $\mathrm{cmol}_{\mathrm{c}} \mathrm{kg}^{-1}$ & 0.36 & Low \\
\hline Na-exch & $\mathrm{cmol}_{\mathrm{c}} \mathrm{kg}^{-1}$ & 0.11 & Low \\
\hline $\mathrm{CEC}$ & $\mathrm{cmol}_{\mathrm{c}} \mathrm{kg}^{-1}$ & 9.53 & Low \\
\hline $\mathrm{N}$ total & $\%$ & 0.10 & Low \\
\hline Organic C & $\%$ & 1.61 & Low \\
\hline Available P & ppm & 5.15 & Low \\
\hline $\mathrm{Al}$ saturation & $\%$ & 53.29 & High \\
\hline Base saturation & $\%$ & 46.71 & Medium \\
\hline
\end{tabular}

In Table 1 it can be seen that the low $\mathrm{pH}$ of the soil by 4.54 unit, this is due to the soil parent material which is classified as acidic and also due to the contribution of $\mathrm{H}^{+}$ from Al hydrolysis. From Table 1 it can also be seen that Ultisols have a relatively low available of $\mathrm{P}$ by $5.15 \mathrm{ppm}$, caused by acidic $\mathrm{pH}$ and the fixation of $\mathrm{P}$ by $\mathrm{Al}$ which is positively charged, so that $\mathrm{P}$ is difficult to be available to plants $[10,11]$. Acid soil conditions and phosphate ions react quickly with $\mathrm{Al}$ octahedral on clay structures by replacing phenol groups located on the clay surface plane [12], [13]. The reaction produces a very strong bond with $\mathrm{P}$ ions resulting in very little $\mathrm{P}$ ions that can be released again. Table 1 also shows the low Cation Exchange Capacity (CEC), which is $9.53 \mathrm{cmol}_{\mathrm{c}} \mathrm{kg}^{-1}$. Kaolinite clay minerals with type 1 dominate ultisols: 1 , because this soil has undergone further weathering and intensive washing, so that the base cations $(\mathrm{K}, \mathrm{Ca}, \mathrm{Mg}$, and $\mathrm{Na})$ in this soil are also relatively low, by $0.34 ; 2.38 ; 0.36$ dan $0.11 \mathrm{cmol}_{\mathrm{c}} \mathrm{kg}^{-1}$. Area of $U$ that has a fairly high rainfall from $2014-2018 \mathrm{~mm}$ year $^{-1}$ around 2031 - $2909 \mathrm{~mm}_{\text {year }}{ }^{-1}$ so that the base cation is easily washed and lost in the soil. Besides that, Ultisol which is used in this research contains low organic matter so that the content of organic $\mathrm{C}$ and $\mathrm{N}$ total is also low by
$1.61 \% \mathrm{C}$ and $0.10 \% \mathrm{~N}$ which shows a low level of soil fertility.

\section{F. Effect of Sub-bituminous Coal and Sub-bituminous Coal Activated with Urea of Ultisols}

In Figure 1 it is seen that the effect of giving only Subbituminous coal and which is activated by Urea is very real on the chemical properties of Ultisols.

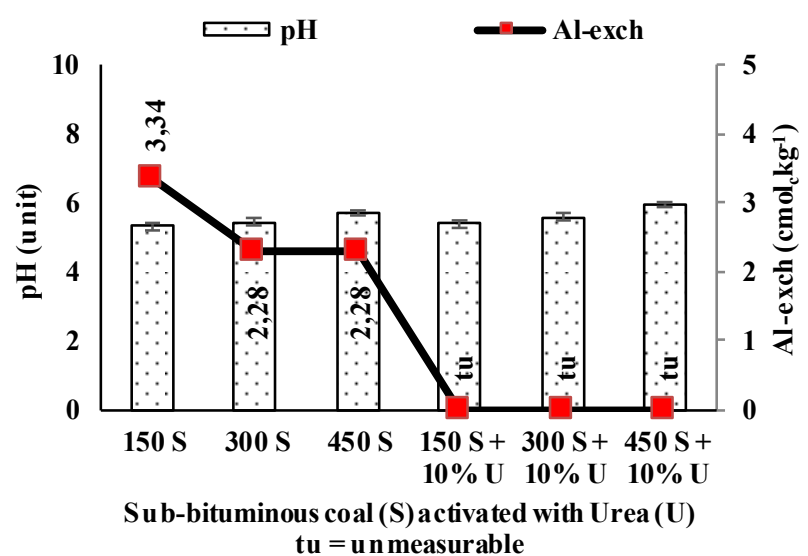

(a)

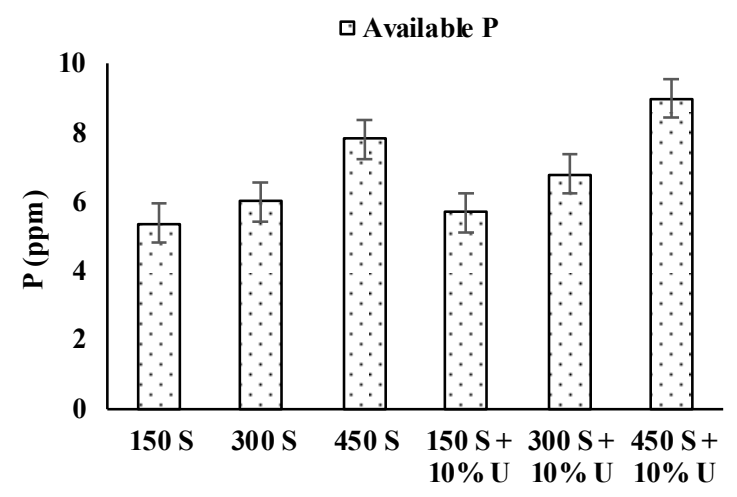

Sub-bituminous coal (S) activated with Urea (U)

(b)

Fig. 1 Effect of Sub-bituminous coal activated with Urea on $\mathrm{pH}$ and Al-exch (a); and P-available (b) at Ultisols

Addition $450 \mathrm{~g}$ Sub-bituminous (planting hole) ${ }^{-1}$ can increase the $\mathrm{pH}$, available $\mathrm{P}, \mathrm{CEC}$ as well as the content of organic $\mathrm{C}$ and $\mathrm{N}$ total by 0.42 unit; $2.46 \mathrm{ppm} \mathrm{P} ; 14.81$ $\mathrm{cmol}_{\mathrm{c}} \mathrm{kg}^{-1} ; 1.01 \% \mathrm{C}$ and $0.12 \% \mathrm{~N}$ as well as reducing $\mathrm{Al}-$ exch by $1.06 \mathrm{cmol}_{\mathrm{C}} \mathrm{kg}^{-1}$, compared to $150 \mathrm{~g}$ (planting hole) ${ }^{-1}$. While after the activation process using $10 \%$ of Urea amounting to 0.65 unit; 3.60 ppm P; $22.09 \mathrm{cmol}_{\mathrm{c}} \mathrm{kg}^{-1} ; 1.11 \%$ $\mathrm{C}$ and $0.17 \% \mathrm{~N}$ as well as reducing Al-exch unmeasurable, compared to $150 \mathrm{~g}$ (planting hole) ${ }^{-1}$ (Figure 1 and 2).

In general, the addition of Sub-bituminous coal can increase nutrient content due to the contribution of humic substances contained in Sub-bituminous coal which is the most reactive component of organic matter in the soil. Increased soil $\mathrm{pH}$ and decreased $\mathrm{Al}$-exch due to Subbituminous coal containing humic compounds that have a carboxyl functional group $(\mathrm{COOH})$ that can bind $\mathrm{Al}^{3+}$ with the binding of Al. 
The Al hydrolysis process can be overcome and the amount of $\mathrm{H}^{+}$produced decreases so that the soil $\mathrm{pH}$ increases. A increase in the dose of humic acid makes an increase in carboxyl groups $(-\mathrm{COOH})$ and phenolic groups ($\mathrm{OH})$ in considerable amounts. The increase can interact with metal ions such as $\mathrm{Al}$ forming complex or chelate compounds so that the $\mathrm{Al}$ solubility decreases and the $\mathrm{pH}$ increases [14]. The increase of available P by giving Subbituminous coal as a result of $\mathrm{Al}$ chelating by organic acids, so that $\mathrm{P}$ is released and available in the soil and the content of available $P$ is increasing. While an increase in CEC at Ultisols. This is presumably because the higher the dose of Sub-bituminous coal that is given, the more humic material that is donated containing carboxyl (-COOH) and phenolic ($\mathrm{OH})$ groups so that the source of the negative charge will increase as well.

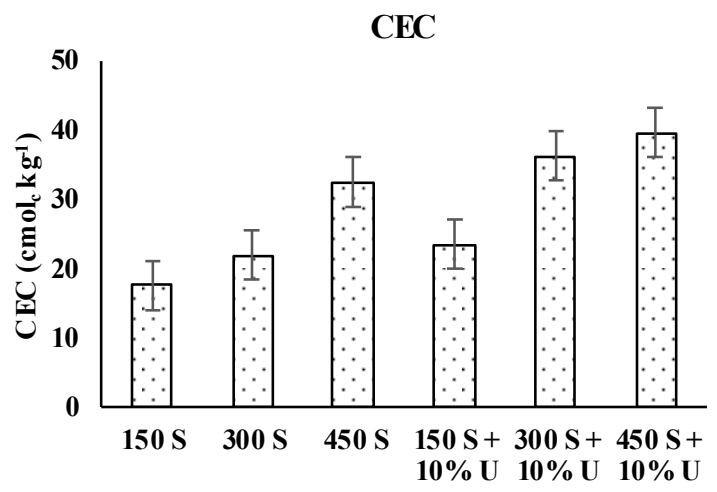

Sub-bituminous coal (S) activated with Urea (U)

(a)

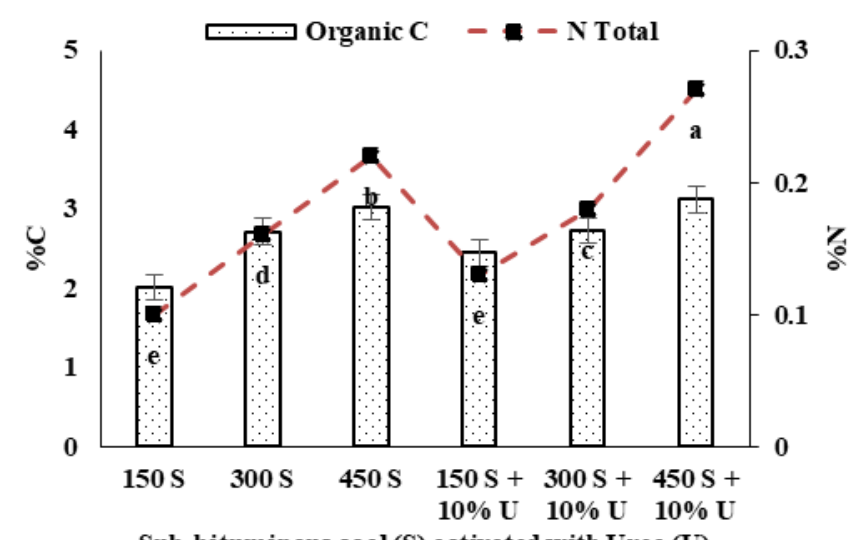

Sub-bituminous coal (S) activated with Urea (U)

(b)

Fig. 2 Effect of Sub-bituminous coal activated with Urea on CEC (a); organic $\mathrm{C}$ and $\mathrm{N}$ total (b) at Ultisols

The increasing amount of negative charge on the colloidal soil causes the soil CEC will also increase. Humic acid has a CEC of $300-1400 \mathrm{cmol}_{\mathrm{c}} \mathrm{kg}^{-1}$, so that the administration of humic material can increase the soil's ability to absorb and exchange cations [15], [16]. Giving Urea as an activating agent causes hydrolyzed Urea to form ammonium carbonate, an unstable compound, and decompose into ammonia and carbon dioxide. Ammonia compounds when reacting with water will form ammonium and hydroxide. The presence of $\mathrm{OH}^{-}$ions in the soil can suppress ions $\mathrm{H}^{+}$so that it can increase $\mathrm{pH}$ [17]-[19]. Giving sub-bituminous which Urea activates can also increase available $\mathrm{P}$ of Ultisol. This is thought to occur because the activator of hydrolyzed Urea will produce $\mathrm{OH}^{-}$which can release $\mathrm{P}$ bound by $\mathrm{Al}$ so that $\mathrm{P}$ can be available in the soil. Urea activator can also increase the value of soil CEC. This is due to Urea's activation when hydrolyzed to donate $\mathrm{OH}^{-}$so that the dissociation of $\mathrm{H}^{+}$from the carboxylic group contained in Sub-bituminous coal can increase the negative charge resulting in increased CEC in soil.

In Fig. 2 (b), it can be seen that the addition of subbituminous could be increase organic-C of Ultisol. This is caused by Sub-bituminous coal, which contains high carbon content. The C content in Sub-bituminous coal is $46.3 \%$ so that the increase in Organic $\mathrm{C}$ derived from Sub-bituminous coal becomes high [20]. The greater the dose of Subbituminous coal activated by Urea, the higher the Organic C. It is suspected that there is a contribution of $\mathrm{C}$ from Urea and has been able to activate the $\mathrm{C}$ in the Sub-bituminous coal. The dissolved sub-bituminous coal can dissociate rapidly in the soil [8]. It is caused by the Urea and $\mathrm{H}_{2} \mathrm{O}$ when inserted into the soil, will contribute $\mathrm{CO}_{2}$ and $\mathrm{NH}_{4} \mathrm{OH}$, assisted by the urease enzyme, will activate soil microorganisms in decomposing soil organic matter, especially Sub-bituminous.

Giving Urea as a Sub-bituminous coal activator can also increase the N-total content. This is presumably because the application of Urea as an activating material contributes $\mathrm{N}$ to the soil. Urea contains $46 \% \mathrm{~N}$ and is easily hydrolyzed so it is easily soluble in water, easily draws water from the air, and has rapid influence on plant growth and development.

\section{G. Effect of Sub-bituminous Coal and Sub-bituminous Coal Activated Urea of Growth Palm Oil (Elaeis guineensis Jacq.)}

The effect of applying Sub-bituminous coal and subbituminous activated with $10 \%$ of Urea on palm oil's growth rate (height, midrib, the number of stem and diameter of stem at 1 year old) in the field observed every month for 6 observations can be seen in Figure 3.

In Figures 3 (a), (b), (c), and (d), giving Sub-bituminous coal and Sub-bituminous coal activated with $10 \%$ of Urea can improve the growth of palm oil in the field where height increases, number of midribs and diameters plant. This is due to improve the chemical properties of Ultisols that can support plant roots' development well because of the availability of nutrients with a balanced amount. Good root development will show good growth in the upper part of the plant. The more the dose of Sub-bituminous coal is given, the higher the height, the diameter of the stem, and the amount of oil palm fronds. Application of $450 \mathrm{~g}$ (planting hole $)^{-1}$ shows plant height, stem diameter, stem circumference and the number of fronds has increased by $45.33 ; 4 ; 0.9$ and $1.88 \mathrm{~cm}$, compared to $150 \mathrm{~g}$ (planting hole $)^{-1}$. While after the activation process using $1 \%$ of Urea amounting to $80.33 ; 6 ; 1.57$ and $2.71 \mathrm{~cm}$, compared to $150 \mathrm{~g}$ (planting hole) $^{-1}$ of Sub-bituminous. The HS contained in Sub-bituminous coal has a better ability to improve the chemical conditions in the root environment so that the roots will be able to develop better and nutrients can be absorbed by the roots so that plant growth is better [21], [22]. The increasing growth of palm oil is caused by increased 
nutrients in the soil. One of the efforts that can be made to increase the rate of plant growth is by providing an optimal supply of nutrients to plants [23]. It is reported that the element $\mathrm{N}$ plays a role in stimulating plants' vegetative growth by increasing plant height [24], [25]. Besides the element $\mathrm{N}$ has a very important role for plants as a constituent of amino acids, amides, nucleotides, and essential for cell division and cell enlargement so that it impacts on the increase in plant height, stem diameter and the number of oil palm fronds at the age of 1 year in the field.

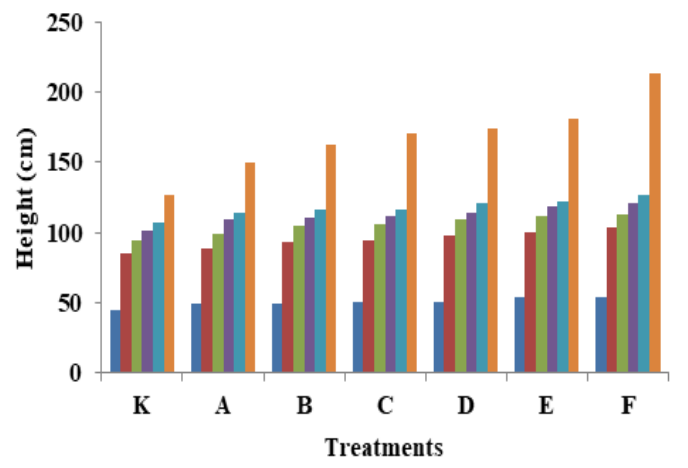

(a)

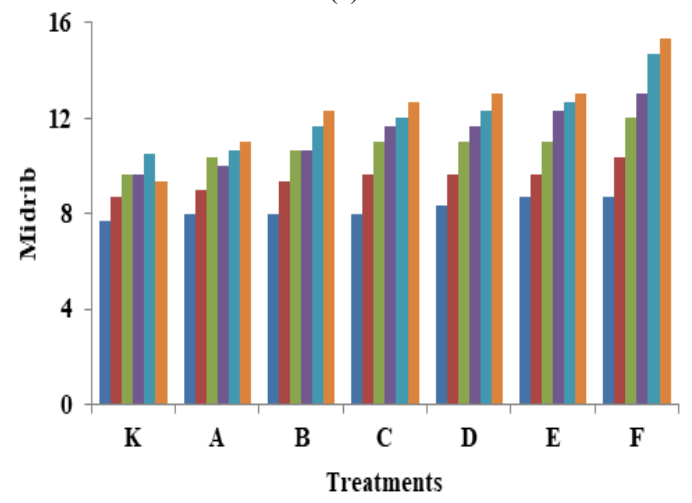

(b)

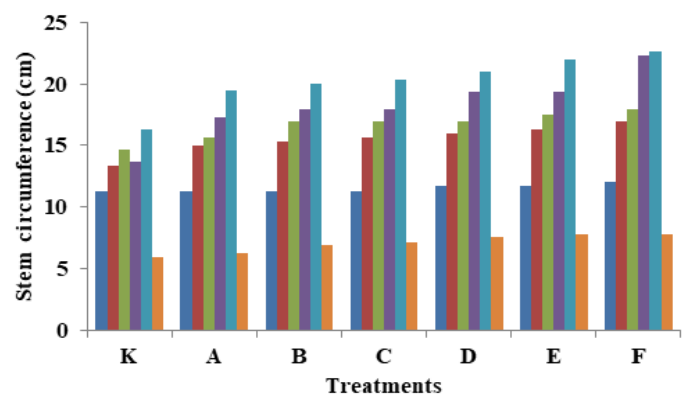

(c)

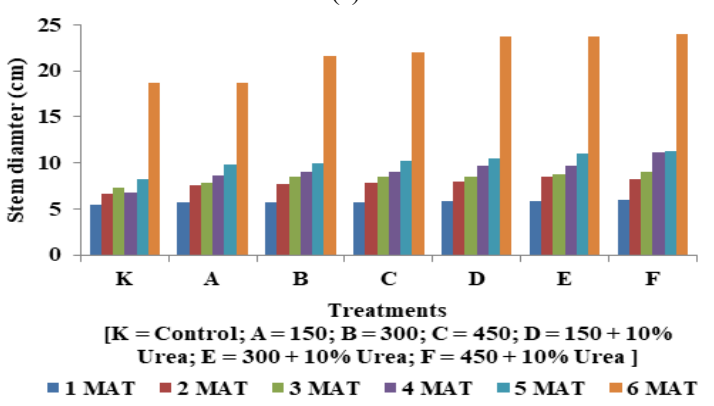

(d)

Fig. 3 Observation of palm oil (Elaeis guineensis Jacq.) for 6-month after treatment (MAT) on height (a); the number of midribs (b); stem circumference (c) and stem diameter (d)

\section{Effect of Sub-bituminous Coal and Sub-bituminous Coal Activated Urea of Nutrient Content Palm Oil (Elaeis guineensis Jacq.)}

The results of observations of the number of nutrients $\mathrm{N}$, $\mathrm{P}$ and $\mathrm{K}$ of palm oil at the age of 1 year can also be seen in Figure 4 where the higher the dose of sub-bituminous powder that is given the higher the nutrient levels of palm oil, both in the administration of Sub-bituminous coal only, and Sub-bituminous coal which activated by Urea. The plant growth, the administration of Sub-bituminous $450 \mathrm{~g}$ (planting hole) $)^{-1}$ is also able to increase $\mathrm{N}, \mathrm{P}$, and $\mathrm{K}$ levels of plant by $0.02 \% ; 0.01 \%$ and $0.01 \%$ compared to the dose of $150 \mathrm{~g}$ (planting hole) $)^{-1}$, while compared to the dose of $300 \mathrm{~g}$ (planting hole) $^{-1}$ show that the levels of $\mathrm{N}$ are almost the same, but can increase levels of $\mathrm{P}$ and $\mathrm{K}$ by $0.01 \%$ and $0.01 \%$ of the plant when compared to $150 \mathrm{~g}$ (planting hole) ${ }^{-1}$.

The highest nutrient content was obtained by treatment of $450 \mathrm{~g}$ Sub-bituminous $+10 \%$ Urea (planting hole) $)^{-1}$ where there was an increase in nutrient levels respectively by $0.03 \% \mathrm{~N}, 0.01 \% \mathrm{P}$, and $0.01 \% \mathrm{~K}$ compared with $150 \mathrm{~g}$ of Sub-bituminous coal without Urea. While the addition of $150 \mathrm{~g}$ Subbituminous $+10 \%$ Urea showing levels of nutrients $\mathrm{N}, \mathrm{P}$, and $\mathrm{K}$ which is almost the same as with $450 \mathrm{~g}$ of Sub-bituminous coal alone and the administration of 300 $\mathrm{g}$ of Sub-bituminous $+10 \%$ urea (Fig. 5).

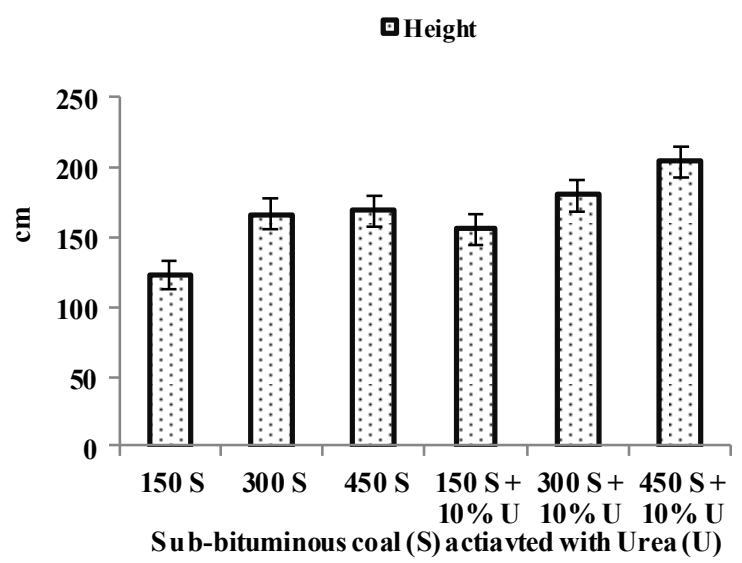

(a)

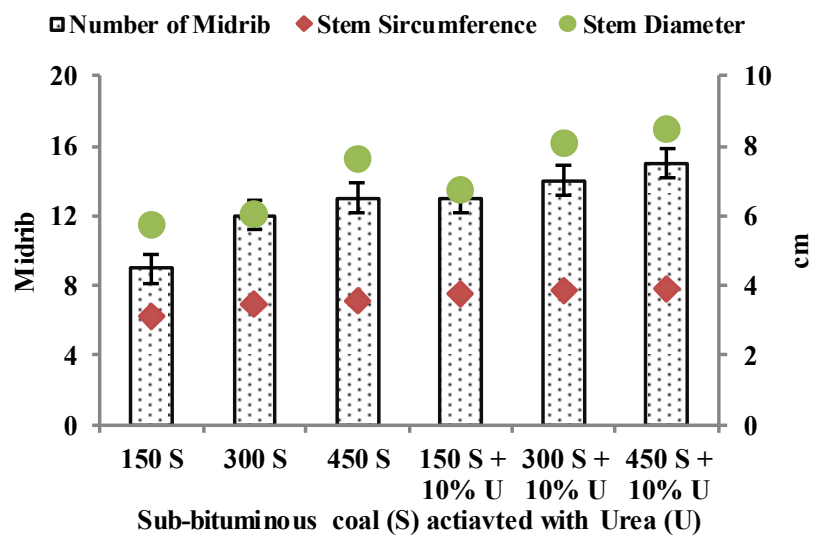

(b)

Fig. 4 Statistical analysis of plant for the effect of Sub-bituminous coal activated with Urea on height (a); the number of midribs, stem circumference, and diameter (b) 
An increase in plant $\mathrm{N}, \mathrm{P}$, and $\mathrm{K}$ levels with an increase in Sub-bituminous coal dosage is in line with improving soil chemical properties (Fig. 1 and 2) which can provide sufficient nutrients for root development and growth of palm oil (Figure 4). The provision of organic compounds in the form of humic substances can increase nutrient uptake by plants such as N, P and K [26]-[28]. P plays a role in the process of cell division and the process of respiration, thereby encouraging plant growth, including division of the number of leaves [29]. K element plays a role in stimulating plant growth points and strengthening vigor which can influence the large stem circle [30]. Sub-bituminous powder with Urea activator has higher plant $\mathrm{N}$ levels than without giving Urea. This is because Urea contains $45 \% \mathrm{~N}$ and can help plant vegetative growth faster. Giving $\mathrm{N}$ in the form of Urea, which is increasingly influential on plant growth, is related to the adequacy of nutrients supplied and absorbed by plants.

\section{$\square \mathbf{N} \square \mathbf{P} \square \mathbf{K}$}

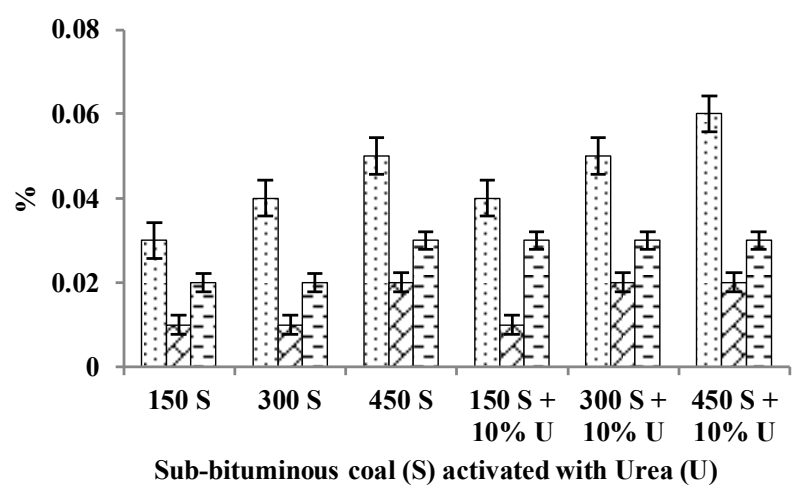

Fig. 5 Effect of Sub-bituminous coal activated with Urea on the nutrient content of palm oil (Elaeis guineensis Jacq.)

Besides that, in Figure 5 it can also be seen that the application of Sub-bituminous powder at a dose of $450 \mathrm{~g}$ (planting hole $)^{-1}$ activated by Urea can increase plant $\mathrm{P}$ levels in line with the increasing available $\mathrm{P}$ soil content and decreasing soil Al-exch content (Figure 1). Organic acids cause increased levels of $P$ in the Sub-bituminous powder that binds $\mathrm{Al}$ to form complex compounds so that $\mathrm{P}$ bound by $\mathrm{Al}^{3+}$ is released and causes $\mathrm{P}$ elements to be available so that plants can absorb more $\mathrm{P}$ elements than without giving an activating agent [31]. Likewise, the increase in the $\mathrm{K}$ content of plants is in line with the increase in K-exch of the soil and the improvement of soil chemical properties (Figure 1). Element K's availability in the soil is strongly influenced by the $\mathrm{pH}$ value and cation exchange capacity (CEC) [32]. The greater cation exchange capacity (CEC) increases the ability of the soil to retain K. Nutrients $\mathrm{K}$ for plants has an important role in the formation of proteins and carbohydrates, improves the quality of seeds or fruit, and strengthens plant stems so that leaves, flowers, and fruit do not fall off easily [33].

\section{CONCLUSIONS}

Based on the results of research that have been carried out it can be concluded that: (1) Giving Sub-bituminous coal $450 \mathrm{~g}$ (planting hole $)^{-1}$ increases soil $\mathrm{pH}, \mathrm{N}$ total, available $\mathrm{P}$, organic C, CEC soil, N-Plant, Plant height respectively with a pH of 0.42 units; $0.12 \% \mathrm{~N} ; 2.46 \mathrm{ppm} \mathrm{P} ; 1.01 \% \mathrm{C} ; 14.91$ cmol $_{\mathrm{c}} \mathrm{kg}^{-1} \mathrm{CEC} ; 0.19 \% \mathrm{~N}$ plants; $45.33 \mathrm{~cm}$ compared with a dose of $150 \mathrm{~g}$ (planting hole) $^{-1}$ (2) Application of $450 \mathrm{~g}$ (planting hole) $)^{-1}$ of Sub-bituminous coal activated with $10 \%$ Urea increases soil $\mathrm{pH}$, total-N, available $\mathrm{P}$, organic-C, CEC and N-Plant content, and Plant height respectively by 0.57 unit; $0.13 \% \mathrm{~N} ; 3.25$ ppm P; $0.69 \% \mathrm{C} ; 16,14$ cmol $_{\mathrm{c}} \mathrm{kg}^{-1} \mathrm{CEC}$; $0.14 \%$ of $\mathrm{N}$ plants; $48.34 \mathrm{~cm}$ compared with a dose of $150 \mathrm{~g}$ (planting hole $)^{-1}$ (3) Provision of the same dosage Subbituminous powder, i.e. at the dose of $450 \mathrm{~g}$ (planting hole) ${ }^{-1}$ activated by Urea, increases $\mathrm{pH}$, Organic $\mathrm{C}$, available $\mathrm{P}$, Total-N, CEC, Plant height, and number of midribs by 0.23 unit; $0.11 \% \mathrm{C} ; 1.14 \% \mathrm{P} ; 0.05 \% \mathrm{~N} ; 7,18 \mathrm{cmol}_{\mathrm{C}} \mathrm{kg}^{-1} \mathrm{CEC}$; $35.67 \mathrm{~cm}$ plant height; 2 pieces of midrib compared with the administration of $450 \mathrm{~g}$ (planting hole) $)^{-1}$ of Sub-bituminous coal without the use of Urea activating agent.

\section{ACKNOWLEDGMENT}

We are grateful to the Rector and Chairman of the Institute for Research and Community Service of Universitas Andalas Padang. This research is under the Ministry of Research Technology and the Higher Education Republic of Indonesia's research grant of professorship.

\section{REFERENCES}

[1] Sulaiman, A. A., Sulaeman, Y., \& Minasny, B. A framework for the development of wetland for agricultural use in Indonesia. Resources, 8(1), 2019, pp. 1-16. DOI: 10.3390/resources 8010034

[2] Zhao, X. Q., and Shen, R. F. Aluminum-nitrogen interactions in the soil-plant system. Frontiers in Plant Science, 9(June), 2018, pp. 1-15. DOI: $10.3389 /$ fpls.2018.00807

[3] Rezki, D., F. Ahmad dan Gusnidar. (2014). Ekstraksi Bahan Humat Dari Batubara (Subbituminus) Dengan 10 Jenis Pelarut. Jurnal Solum, 6 (2). 2014. ISSN. 1829-7994

[4] Herviyanti, Gusnidar, Harianti, M., and Maulana, A. Improvement Chemical Properties of Oxisols and Rice Production with Humic Substances from Sub-bituminous Coal Indonesia. Agrivita. 41(3), 2019, pp. 428-438. DOI: 10.17503/agrivita.v41i3.1106

[5] Herviyanti., Ahmad. F., Gusnidar dan Saidi. A. Potensi Batubara Tidak Produktif (Subbitumminus) Sebagai Sumber Bahan Organik Alternatif Untuk Meningkatkan Efisiensi Pemupukan $\mathrm{P}$ dan Produktifitas Tanah Marginal. Laporan Hibah Strategis Nasional Batch II. 2009. 50 p.

[6] Rahmi, E., Suwardi, S., and Sumawinata, B. Characterization of Humic Substance Extracted from Andisols, Spodosols, Peat, and Lignite. Sains Tanah - Journal of Soil Science and Agroclimatology, 15(1), 2018, pp. 35. DOI: 10.15608/stjssa.v15i1.21622

[7] Herviyanti, Yusnaweti, Prasetyo, T.B., Harianti, M. Kajian Stabilitas Bubuk Batubara Terhadap Produktifitas dan Bahan Humatnya Dalam meningkatkan Produksi Oxisol dan Ultisol. Laporan Penelitian KKP3N. 2013. 48 p.

[8] Herviyanti, Yusnaweti dan Rasyidin, A. Kajian Stabilitas Bubuk Batubara tidak Produktif dan Bahan Humatnya yang Diekstrak dengan Pupuk Buatan untuk meningkatkan Efisiensi Pemupukan dan Produktifitas Ultisol dan oxisol. Laporan Hasil Penelitian. Badan penelitan dan Pengembangan Pertanian. 2014. 55 p.

[9] Balai Penelitian Tanah. Analisis Kimia Tanah, Tanaman, Air dan Pupuk.Badan Penelitian dan Pengembangan Pertanian Departemen Pertanian. 2012. 211 p.

[10] Hemwall, J. B. The Fixation of Phosphorus by Soils. Advances in Agronomy, 9(C), 1957, pp. 95-112. DOI: 10.1016/S00652113(08)60110-8

[11] Chatterjee, D., Datta, S. C., and Manjaiah, K. M. Fractions, uptake and fixation capacity of phosphorus and potassium in three contrasting soil orders. Journal of Soil Science and Plant Nutrition, 14(3), 2014, pp. 640-656. DOI: 10.4067/s0718-95162014005000051

[12] Fink, J. R., Inda, A. V., Tiecher, T., and Barrón, V. Iron oxides and organic matter on soil phosphorus availability. Ciencia e 
Agrotecnologia, 40(4), 2016, pp. 369-379. DOI: 10.1590/141370542016404023016

[13] Adeyemo, A. A., Adeoye, I. O., and Bello, O. S. Adsorption of dyes using different types of clay: a review. Applied Water Science, 7(2), 2017, pp. 543-568. DOI: 10.1007/s13201-015-0322-y

[14] Sudiono, S., Yuniarti, M., Siswanta, D., Kunarti, E. S., Triyono, and Santosa, S. J. The role of carboxyl and hydroxyl groups of humic acid in removing AuCl4- from aqueous solution. Indonesian Journal of Chemistry, 17(1), 2017, pp. 95-104. DOI: 10.22146/ijc.23620

[15] Mindari, W., Aini, N., and Kusuma, Z. Effects of humic acid-based buffer + cation on chemical characteristics of saline soils and maize growth. Journal of Degraded and Mining Lands Management, 2(1), 2014, pp. 259-268. DOI: 10.15243/jdmlm.2014.021.259

[16] Boguta, P., and Sokołowska, Z. Interactions of $\mathrm{Zn}$ (II) Ions with Humic Acids Isolated from Various Type of Soils. Effect of $\mathrm{pH}, \mathrm{Zn}$ Concentrations, and Humic Acids Chemical Properties. PLoS ONE, 11(4), 2016, pp. 1-20. DOI: 10.1371/journal.pone.0153626

[17] Tisdale, S and Nelson, W. Soil Fertility and Fertilizer. Third Edition. New York: Macmillan Publishing. Co., Inc. 1975. 694 p.

[18] Iqbal, M. T. Effect of Al compounds on soil $\mathrm{pH}$ and bioavailability of $\mathrm{Al}$ in two acid soils. Turkish Journal of Agriculture and Forestry, 36(6), 2012, pp. 720-728. DOI: 10.3906/tar-1109-26

[19] Kunhikrishnan, A., Thangarajan, R., Bolan, N. S., Xu, Y., Mandal, S., Gleeson, D. B., Seshadri, B., Zaman, M., Barton, L., Tang, C., Luo, J., Dalal, R., Ding, W., Kirkham, M. B., and Naidu, R. Functional Relationships of Soil Acidification, Liming, and Greenhouse Gas Flux. Advances in Agronomy, 139 (October 2017), 2016, pp. 1-71. DOI: 10.1016/bs.agron.2016.05.001

[20] Poertadji, S., Nukman and Hikam, $M$ The Effect of The Agglomerating of Water-Oil Palm to Carbon Content and Calorific Value of SemiAnthracite, Bituminous, and Sub-bituminous Coals. J. Indonesia Materials Sci. 7: 2016. p 68-74

[21] Nardi, S., Pizzeghello, D., Muscolo, A., and Vianello, A. Physiological effects of humic substances on higher plants. Soil Biology and Biochemistry, 34(11), 2002, pp. 1527-1536. DOI: 10.1016/S0038-0717(02)00174-8

[22] Trevisan, S., Francioso, O., Quaggiotti, S., and Nardi, S. Humic substances biological activity at the plant-soil interface: From environmental aspects to molecular factors. Plant Signaling and Behavior, 5(6), 2010, pp. 635-643. DOI: 10.4161/psb.5.6.11211

[23] Gardner F.P., Pearce R.B., and Mitchell R.L. Fisiologi tanaman budidaya. Penerjemah S. Herawati. Penerbit UI.1991. 424 p
[24] Setyamidjaja, D. Budidaya Kelapa Sawit. Yogyakarta (ID): Kanisius. $200674 \mathrm{p}$

[25] Ramírez-Olvera, S. M., Trejo-Téllez, L. I., García-Morales, S., PérezSato, J. A., and Gómez-Merino, F. C. Cerium enhances germination and shoot growth, and alters mineral nutrient concentration in rice. PLoS ONE, 13(3), 2018, pp. 1-19. DOI: 10.1371/journal.pone.0194691

[26] Nikbakht, A., Kafi, M., Babalar, M., Xia, Y. P., Luo, A., \& Etemadi, N. A. Effect of humic acid on plant growth, nutrient uptake, and postharvest life of gerbera. Journal of Plant Nutrition, 31(12), 2008, pp. 2155-2167. DOI: 10.1080/01904160802462819

[27] Verlinden, G., Pycke, B., Mertens, J., Debersaques, F., Verheyen, K., Baert, G., Bries, J., \& Haesaert, G. Application of humic substances results in consistent increases in crop yield and nutrient uptake. Journal of Plant Nutrition, 32(9), 2009, pp. 1407-1426. DOI: $10.1080 / 01904160903092630$

[28] Ali, M., and Mindari, W. Effect of humic acid on soil chemical and physical characteristics of an embankment. MATEC Web of Conferences, 2016, pp 58. DOI: 10.1051/matecconf/20165801028

[29] Hasanuzzaman, M., Fujita, M., Oku, H., Nahar, K., and HawrylakNowak, B. Plant nutrients and abiotic stress tolerance. Plant Nutrients and Abiotic Stress Tolerance, July 2018, pp. 1-590. DOI: 10.1007/978-981-10-9044-8

[30] Razaq, M., Zhang, P., Shen, H. L., and Salahuddin. Influence of nitrogen and phosphorous on the growth and root morphology of Acer mono. PLoS ONE, 12(2), 2017, pp. 1-13. DOI: 10.1371/journal.pone.0171321

[31] Quan-xian, H. U. A., Jian-yun, L. I., Jian-min, Z., Huo-yan, W., and Chang-wen, D. U. Enhancement of Phosphorus Solubility by Humic. 18(30400273), 2008, pp. 533-538.

[32] Fontes, M. P. F., and Alleoni, L. R. F. Electrochemical attributes and availability of nutrients, toxic elements, and heavy metals in tropical soils. Scientia Agricola, 63(6), 2006, pp. 589-608. DOI: 10.1590/s0103-90162006000600014

[33] Rahman, M. A., Lee, S. H., Ji, H. C., Kabir, A. H., Jones, C. S., and Lee, K. W. (2018). Importance of mineral nutrition for mitigating aluminum toxicity in plants on acidic soils: Current status and opportunities. International Journal of Molecular Sciences, 2018, pp. 19(10). DOI: 10.3390/ijms19103073 